\title{
Pengembangan Media Puzzle Susun Kotak Pada Tema Ekosistem
}

\author{
Lutfi Andi Darmawan1*, Fine Reffiane², Sunan Baedowi ${ }^{3}$ \\ 123 Prodi Pendidikan Guru Sekolah Dasar Fakultas Ilmu Pendidikan Universitas PGRI Semarang
}

\begin{abstract}
Abstrak
Latar belakang penelitian ini adalah penggunaan media pembelajaran yang masih rendah. Media puzzle susun kotak dapat digunakan untuk mendukung kegiatan pembelajaran dan meningkatkan konsentrasi belajar siswa. Tujuan penelitian ini adalah untuk mengetahui kevalidan dan kepraktisan media puzzle susun kotak yang digunakan untuk siswa kelas V sekolah dasar. Jenis penelitian ini adalah penelitian dan pengembangan dengan menggunakan prosedur pengembangan model ADDIE. Penelitian ini dilaksanakan pada 3 sekolah dasar yaitu SD Negeri 2 Dermolo, SD Negeri 1 Balong dan SD Negeri 2 Balong. Hasil uji kevalidan diperoleh dari penilaian ahli media sebesar 99\% (baik sekali) dan penilaian ahli materi sebesar 98\% (baik sekali). Sedangkan hasil uji kepraktisan diperoleh dari penilaian respon guru sebesar 98\% (baik sekali) dan penilaian respon siswa sebesar 96\% (baik sekali). Kesimpulannya bahwa media puzzle susun kotak valid dan praktis digunakan untuk siswa kelas V sekolah dasar.
\end{abstract}

Keywords:

Addie,

puzzle, ekosistem

\section{PENDAHULUAN}

Pendidikan adalah usaha sadar dan terencana untuk mewujudkan suasana belajar dan proses pembelajaran agar peserta didik secara aktif mengembangkan potensi dirinya untuk memiliki kekuatan spiritual keagamaan, pengedalian diri, kepribadian, kecerdasan akhlak mulia, serta keterampilan yang diperlukan dirinya, masyarakat, bangsa dan Negara (Undang-undang Sistem Pendidikan Nasional Tahun 2003 Nomor 20 Bab 1 Pasal 1 Ayat 1). Salah satu penunjang keberhasilan yang lebih berkualitas dengan meningkatkan penggunaan media pembelajaran.

Hal ini sejalan dengan pengertian media pembelajaran menrut Kustandi dan Bambang (2013: 9) mengatakan bahwa media pembelajaran adalah alat yang dapat membantu proses belajar mengajar dan berfungsi untuk memperjelas makna pesan yang disampaikan, sehingga dapat mencapai tujuan pembelajaran dengan lebih baik dan sempurna.

Menurut Jannah (2018: 121) Permainan puzzle adalah sebuah permainan yang bertujuan untuk melatih anak untuk lebih berfikir kreatif dalam merangkai gambar puzzle yang sudah disiapkan. Menurut Jannah (2018: 121) permainan puzzle memiliki tujuan sebagai berikut: 1) permainan puzzle bertujuan untuk melatih anak untuk berfikir kreatif; 2) Permainan puzzle dapat mengembangkan aspek kognitif dan motorik halus pada anak.

Berdasarkan hasil wawancara ke sekolah dasar dengan guru kelas V SD Negeri 2 Dermolo, SD Negeri 1 Balong dan SD Negeri 2 Balong. Terdapat kesimpulan berkaitan dengan permasalahan yang terjadi didalam pembelajaran, yaitu penggunaan media pembelajaran masih rendah yang diakibatkan dalam membuat media pembelajaran dengan mengaitkan beberapa mata pelajaran lebih susah dari pada pembuatan media pembelajaran untuk satu mata pembelajaran. Akibat tanpa adanya media pembelajaran yang bervariasi, konsentrasi belajar siswa di dalam kelas menjadi kurang. Konsentrasi siswa pada 
pembelajaran rata-rata hanya sepuluh hingga lima belas menit saja. Selain itu, siswa terkadang melakukan kegiatan yang tidak berhubungan dengan kegiatan pembelajaran.

Media puzzle merupakan pengembangan dari media pembelajaran puzzle yang telah dilakukan oleh peneliti terdahulu. Adapun peneliti terdahulu tentang media pembelajaran puzzle yaitu "Pengembangan Media Puzzle Rantai Makanan Untuk Mata Pelajaran Ilmu Pengetahuan Alam SD" penelitian ini dilakukan oleh Septika Winanti tahun 2014. Penelitian pengembangan ini bertujuan untuk menghasilkan media puzzle rantai makanan untuk mata pelajaran IPA yang layak untuk siswa kelas IV SD.

Mengingat kurangnya penggunaan media dalam proses belajar mengajar didalam sekolah dasar, maka penulis tertarik untuk melakukan penelitian yang berhubungan dengan media pembelajaran, yaitu dengn judul "Pengembangan Media Puzzle Susun Kotak pada Tema Ekosistem untuk Siswa Kelas V Sekolah Dasar".

\section{METODE PENELITIAN}

Metode yang digunakan dalam penelitian adalah penelitian dan pengembangan. Menurut Sukmadinata, Nana Syaodih (2017: 164) penelitian dan pengembangan atau Research and Development (R\&D) adalah suatu proses atau langkah-langkah untuk mengembangkan suatu produk baru atau menyempurnakan produk yang telah ada, yang dapat dipertanggungjawabkan. Desain model penelitian ini yaitu menggunakan desain model ADDIE (Analysis, Design, Development, Implementation, and Evaluation).

Subyek penelitian ini adalah siswa kelas V sekolah dasar di daerah kecamatan Kembang kabupaten Jepara. Sekolah dasar tersebut yaitu SD Negeri 2 Dermol, SD Negeri 1 Balong dan SD Negeri 2 Dermolo. Teknik pengumpulan data yang digunakan untuk mengetahui validitas dan kepraktisan produk pengembangan yaitu angket atau kuesioner. Menurut Sukmadinata, Nana Syaodih (2017: 219) angket atau kuesioner merupakan suatu teknik atau cara pengumpulan data secara tidak langsung (peneliti tidak langsung bertanya jawab dengan responden). Untuk menilai validasi produk pengembangan, angket diberikan kepada ahli media dan ahli materi. Untuk menilai kepraktisan produk pengembangan, angket diberikan kepada guru dan siswa.

\section{ANALISIS DAN PEMBAHASAN}

Produk akhir penelitian ini adalah media puzzle susun kotak pada tema ekosistem untuk siswa kelas V sekolah dasar. Media puzzle susun kotak disusun berdasarkan prosedur pengembangan media yang telah ditetapkan. Langkah pertama yaitu menganalisis permasalahan yang terjadi di sekolah. Setelah itu, peneliti merancang dan mendesain media sesuai dengan permasalahan yang telah didapat. Dalam merancang peneliti harus menyesuaikan degan KD dan indikator dalam pembelajaran. Setelah membuat rancangan, selanjutnya peneliti membuat produk media pembelajaran susun kotak. Media puzzle susun kotak yang sudah jadi selanjutnya divalidasi oleh ahli media dan ahli materi untuk mengetahui kevalidan media puzzle susun kotak. Ahli media dan ahli materi tersebut yaitu bapak Arief Budiman, M.Hum, ibu Ikha Listyarini, M.Hum dan ibu ArfiliaWijayanti, S.Pd., M.Pd.

Hasil validasi media tahap pertama oleh bapak Arief Budiman, M.Hum diperoleh skor sebesar 86\% dengan kriteria "baik sekali", hasil validasi media tahap pertama oleh ibu ikha Listyarini, M.Hum diperoleh skor sebesar 71\% dengan kriteria "baik" dan hasil validasi media tahap pertama oleh ibu Arfilia Wijayanti, S.Pd,. M.Pd diperoleh skor sebesar 86\% dengan kriteria "baik sekali". Sedangkan hasil validasi materi tahap pertama oleh bapak Arief Budiman, M.Hum diperoleh skor sebesar 75\% dengan kriteria "baik", hasil validasi materi tahap pertama oleh ibu Ikha Listyarini, M.Hum diperoleh skor sebesar $68 \%$ dengan kriteria "cukup" dan hasil validasi materi tahap pertama oleh ibu Arfilia Wijayanti, S.Pd,. M.Pd diperoleh skorsebesar 68\% dengan kriteria "cukup".

Berdasarkan hasil validasi media tahap pertama dari ketiga ahli media diperoleh skor rata-rata sebesar $81 \%$ dengan kriteria "baik sekali". Sedangkan hasil validasi materi tahap pertama dari ketiga ahli materi diperoleh skor rata-rata sebesar 70\% dengan kriteria "baik". Dari skor rata-rata validasi ahli media dan ahli materi tahap pertama terhadap media puzzle susun kotak, maka media puzzle susun kotak dapat digunakan dengan revisi.

Hasil validasi media tahap kedua oleh bapak Arief Budiman, M.Hum diperoleh skor sebesar 100\% dengan kriteria "baik sekali", hasil validasi media tahap kedua oleh ibu Ikha Listyarini, M.Hum diperoleh skor sebesar 97\% dengan kriteria "baik sekali" dan hasil validasi media tahap kedua oleh ibu Arfilia Wijayanti, S.Pd,. M.Pd diperoleh skor sebesar 100\% dengan kriteria "baik sekali". Sedangkan hasil validasi materi oleh bapak Arief Budiman, M.Hum diperoleh skor sebesar 100\% dengan kriteria "baik sekali", hasil 
validasi materi tahap kedua oleh ibu Ikha Listyarini, M.Hum diperoleh skor sebesar 97\% dengan kriteria "baik sekali" dan asil validasi materi tahap kedua oleh ibu Arfilia Wijayaanti, S.Pd,. M.Pd diperoleh skor sebesar 98\% dengan kriteria "baik sekali".

Berdasarkan hasil validasi media tahap kedua dari ketiga ahli media diperoleh skor rata-rata sebesar 99\% dengan kriteria "baik sekali". Sedangkan hasil validasi materi tahap kedua dari ketiga ahli materi diperoleh skor rata-rata sebesar 98\% dengan kriteria "baik sekali". Dari skor rata-rata validasi ahli media dan ahli materi tahap kedua terhadap media puzzle susun kotak, maka media puzzle susun kotak valid digunakan

Untuk mengetahui kepraktisan media puzzle susun kotak dapat diperoleh berdasarkan hasil tanggapan guru dan siswa kelas V pada tiga sekolah dasar yaitu SD Negeri 2 Dermolo, SD Negeri 1 Balong dan SD Negeri 2 Balong. Hasil tanggapan guru kelas V SD Negeri 2 Dermolo sebesar 100\% dengan kriteria "baik sekali", hasil tanggapan guru kelas V SD Negeri 1 Balong sebesar 96\% dengan kriteria "baik sekali" dan hasil tanggapan guru kelas V SD Negeri 2 Balong sebesar $90 \%$ dengan kriteria "baik sekali". Sedangkan hasil tanggapan siswa kelas V SD Negeri 2 Dermolo sebesar 99\% dengan kriteria "baik sekali", hasil tanggapan siswa kelas V SD Negeri 1 Balong sebesar 98\% dengan kriteria "baik sekali" dan hasil tanggapan siswa kelas V SD Negeri 2 Balong sebesar 90\% dengan kriteria "baik sekali".

Berdasarkan hasil tanggapan guru kelas V pada tiga sekolah dasar yaitu SD Negeri 2 Dermolo, SD Negeri 1 Balong dan SD Negeri 2 Balong diperoleh skor rata-rata sebesar 98\% dengan kriteria "baik sekali". Sedangkan hasil tanggapan siswa kelas V pada tiga sekolah dasar yaitu SD Negeri 2 Dermolo, SD Negeri 1 Balong dan SD Negeri 2 Balong diperoleh skor rata-rata sebesar 96\% dengan kriteria "baik sekali". Dari skor rata-rata hasil tanggapan guru dan siswa terhadap media puzzle susun kotak, maka media puzzle susun kotak praktis digunakan.

\section{KESIMPULAN}

Dari penelitian ini, dapat diambil kesimpulan bahwa media puzzle susun kotak valid dan praktis digunakan untuk siswa kelas $\mathrm{V}$ sekolah dasar. Hal ini ditunjukkan dengan hasil analisis penilaian angket dari tiga ahli media tahap kedua diperoleh skor rata-rata 99\% dengan kriteria "baik sekali", hasil analisis penilaian angket dari tiga ahli materi tahap kedua diperoleh skor rata-rata $98 \%$ dengan kriteria "baik sekali", hasil analisis penilaian tanggapan guru dari tiga sekolah dasar diperoleh skor rata-rata $98 \%$ dengan kriteria "baik sekali" dan hasil analisis penilaian tanggapan siswa dari tiga sekolah dasar diperoleh skor rata-rata 96\% dengan kriteria "baik sekali".

Berdasarkan penelitian yang telah dilakukan, peneliti dapat memberikan saran yaitu 1) bagi guru dapat menggunakan media pembelajaran puzzle susun kotak sebagai sarana pembelajaran untuk menarik perhatian siswa dan meningkatkan konsentrasi belajar siswa; 2) bagi peneliti lain dapat dilakukan pengembangan selanjutnya guna menyempurnakan produk ini dan menjadi produk baru dalam penelitian pengembangan tentang media pembelajaran.

\section{DAFTAR PUSTAKA}

Arikunto, Suharsimi. 2010. Prosedur Penelitian Suatu Pendekatan Praktik.Jakarta: PT. Rineka Cipta.

Aqib, Zainal. 2009. Penelitian Tindakan Kelas. Bandung: Yrama Widya.

Dimyati dkk. 2009. Belajar dan pembelajaran.Jakarta: PT. Rineka Cipta.Gunawan,

Rudy. 2011. Pendidikan IPS. Bandung: Alfabeta.

Hamalik, Oemar. 2001.Proses Belajar Mengajar. Jakarta: PT. Bumi Aksara.

Indarti, Titik. 2008. Penelitian Tindakan Kelas (PTK) dan Penulisan Ilmiah.Surabaya: Universitas Negeri Surabaya.

Jannah, Aghisni Ika Luluil, 2018. Asyiknya bermain. Yogyakarta: Lontar Mediatama

Khomsoh, Rosiana. 2016. Penggunaan Media Puzzle Untuk Meningkatkan Hasil Belajar Siswa Dalam Pembelajaran Ilmu Pengetahuan Sosial Di Sekolah Dasar. Jurnal PGSD FIP, Universitas Negeri Surabaya vol 2 no 1. 
Kustandi, Cecep dan Bambang Sutjipto. 2013. Media Pembelajaran Manual dan Digital. Bogor: Ghalia Indonesia.

Kustandi, Cecep dkk. 2011. Media Pembelajaran Manual Dan Digital.Bogor: Ghalia Indonesia.

Krishna Murti, Tendi dkk. 2012. 50 Permainan Edukatif Untuk Mengembangkan Potensi dan Mental Positif. Yogyakarta: PT. Citra Aji Parama.

Nisak, Raisatun. 2011.Lebih Dari 50 Game Kreatif Untuk Aktivitas Belajar -Mengajar.Jogjakarta: Diva Press.

Pribadi, Benny A. 2014. Model Desain Sistem Pembelajaran. Jakarta: Dian Rakyat.

Sadiman, Arief dkk. 2010. Media Pendidikan: Pengertian Pengembangan dan Pemanfaatannya. Jakarta: Rajawali Pers.

Suradisastro, Djodjo dkk. 1992. Pendidikan IPS III. Jakarta: Departemen Pendidikan dan Kebudayaan.

Setyosari, Punaji. 2010. Pemanfaatan Media. Malang: Universitas Negeri Malang.

Sugiyono. 2011. Metode Penelitian Kuantitatif, Kualitatif dan R\&D.Bandung: Alfabeta.

Setyosari, Punaji. 2010. Pemanfaatan Media. Malang: Universitas Negeri Malang.

Sudjana, Nana dkk. 2005. Media Pengajaran.Bandung: Sinar Baru Algensindo.

Suciaty al -azizy, A. 2010. Ragam Latiahan Khusus Asah Ketajaman Otak Anak Plus Melejitkan Daya Ingatnya. Jogjakarta: Diva Press.

Sudjana, Nana. 1991. Penilaian Hasil Proses Belajar Mengajar. Bandung: PT. Remaja Rosdakarya Offset.

Slameto. 2010. Belajar Dan Faktor-Faktor Yang Mempengaruhinya. Jakarta: PT. Rineka Cipta.

Supriya. 2011. Pendidikan IPS.Bandung: PT. Remaja Rosdakarya Offset.S.

Sukmadinata, Nana Syaodih. 2017. Metode Penulisan Pendidikan. Bandung: PT Remaja Rosdayakarya.

Trianto dkk. 2010. Mengembangkan Model Pembelajaran Tematik.Jakarta: PT. Prestasi Pustakarya

Undang-undang Dasar Negara Republik Indonesia No. 20 Tahun 2003 Pasal 1 ayat 1 tentang Sistem Pendidikan Nasional.

Winanti, Septika. 2014. Pengembangan Media Puzzle Rantai Makanan Untuk Mata Pelajaran Ilmu Pengetahuan Alam SD. Yogyakarta: Universitas Negeri Yogyakarta. 